\title{
Various nuclear reprogramming systems using egg and oocyte materials
}

\author{
Kei MIYAMOTO ${ }^{1)}$ \\ 1)Laboratory of Molecular Developmental Biology, Faculty of Biology-Oriented Science and Technology, Kindai University, \\ Wakayama 649-6493, Japan
}

\begin{abstract}
Maternal factors stored in eggs and oocytes are necessary for reprogramming sperm for embryonic development. This reprogramming activity of maternal factors also works towards somatic cells, including terminally differentiated cells. Several different experimental systems utilizing egg and oocyte materials have been applied to study nuclear reprogramming by maternal factors. Among these systems, the most widely used is the transfer of a somatic cell nucleus to an oocyte arrested at the metaphase II stage, leading to the production of a cloned animal. Nuclear transfer to an unfertilized oocyte thus provides a unique opportunity to examine reprogramming processes involved in acquiring totipotency. Other experimental systems are also available to study maternal reprogramming, such as nuclear transfer to Xenopus laevis oocytes at the germinal vesicle stage, treatment with extracts obtained from eggs or oocytes, and induced pluripotency with overexpressed maternal factors. Each system can be used for answering different types of scientific questions. This review describes currently available reprogramming systems using egg and oocyte materials and discusses how we can deepen our understanding of reprogramming mechanisms by taking advantage of these various experimental systems.
\end{abstract}

Key words: Egg and oocyte, Maternal factors, Nuclear reprogramming, Nuclear transfer

(J. Reprod. Dev. 65: 203-208, 2019)

\section{Introduction}

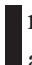
the 1950s, successful cloning using differentiated frog cells was achieved by transplanting the cell nucleus into an unfertilized egg whose genomic materials had been destroyed $[1,2]$. Several decades later, mammalian species were cloned from adult somatic cells [3, 4]. In mammalian nuclear transfer (NT), a somatic nucleus is transferred into an unfertilized, enucleated oocyte. These groundbreaking studies raised an important new question, i.e., how are differentiated cells reprogrammed to the undifferentiated state? Researchers soon realized the value of answering this question, since nuclear reprogramming of somatic cells could pave the way for a wide variety of applications, such as regenerative medicine, the propagation of livestock with important traits, and the preservation of genetic materials from endangered animals. Later, reprogramming of somatic cells to the pluripotent state has been achieved by the production of induced pluripotent stem cells (iPSCs) [5, 6]. iPSCs have already been applied for the treatment of age-related macular degeneration $[7,8]$. However, we still do not fully understand the mechanisms of nuclear reprogramming. In particular, the reprogramming processes of somatic nuclei in eggs and oocytes are not well known and clearly, need further investigation. Some valuable information can only be obtained by studying nuclear reprogramming in eggs and oocytes,

Received: January 10, 2019

Accepted: January 19, 2019

Published online in J-STAGE: February 9, 2019

(C)2019 by the Society for Reproduction and Development

Correspondence: K Miyamoto (e-mail: kmiyamo@waka.kindai.ac.jp)

This is an open-access article distributed under the terms of the Creative Commons Attribution Non-Commercial No Derivatives (by-nc-nd) License. (CC-BY-NC-ND 4.0: https://creativecommons.org/licenses/by-nc-nd/4.0/) which is mediated by maternal factors. NT to eggs or oocytes serves as the only established method to provide somatic cells with totipotency, which is the ability to develop into all of the cells for making up an organism. Rapid and efficient reprogramming can be achieved by NT, such that previously silenced genes are activated in a short period of time [9]. Natural reprogramming activity for sperm is used in NTmediated reprogramming. However, NT is technically demanding. It normally requires years of training and produces only a small number of embryos. Therefore, reprogramming systems that do not use NT, but still utilize egg/oocyte materials, have been developed. In this review, different reprogramming systems using egg/oocyte materials and their characteristics are discussed. Appropriate systems should always be selected to suit the specific research purpose.

\section{Reprogramming towards Totipotency by NT to Eggs/oocytes at the Metaphase II Stage}

Eggs/oocytes that are arrested at the metaphase II (MII) stage are normally used to produce cloned animals. The term "MII egg" is used for frogs, while "MII oocyte" is used for mammals. In both cases, enucleation or disruption of the maternal genome is performed prior to the transplantation of a single somatic nucleus. Transfer of a somatic nucleus to the oocyte cytoplasm can be achieved by microinjection or cell fusion. The reconstructed eggs/oocytes are then activated to start development, although pre-incubation of the reconstructed oocytes to facilitate nuclear reprogramming before activation is desirable in mice. After cell divisions, the reconstructed embryos initiate embryonic gene activation. Until the activation of embryonic genes, the developmental programs of embryos are predominantly controlled by maternally stored factors in eggs/oocytes. Thereafter, embryonically activated genes direct developmental cascades to 
culminate in cloned animals.

NT to MII eggs/oocytes paves the way to produce cloned animals from somatic nuclei and is the only established method to study how a single somatic nucleus is reprogrammed to direct embryonic development to term. In other words, NT to MII eggs/oocytes is a unique method to study the process of acquiring totipotency. NT to eggs/oocytes ensures rapid and efficient reprogramming and can yield embryonic stem (ES) cells of high quality $[10,11]$. Furthermore, when the somatic nucleus of one species is transferred to the oocyte cytoplasm of another related species, the reconstructed interspecies embryos can initiate early developmental events and support development to live offspring in some cases $[12,13]$. In theory, this interspecies NT can be utilized to propagate animals whose germ cells are difficult to obtain, although this technique needs further improvement.

Thus, the value of NT to MII eggs/oocytes has been recognized. However, the efficiency of animal cloning is low due to the frequent errors in nuclear reprogramming. Generally cloning efficiency is less than a few percent. Therefore, many attempts have been made to identify the barriers to nuclear reprogramming that cause low developmental rates in NT embryos. Several key factors that prevent efficient reprogramming have been identified. Firstly, the X chromosome-linked non-coding RNA, Xist, can be abnormally expressed from one of the $\mathrm{X}$ chromosomes that needs to be silenced for normal development [14]. Abnormal Xist expression triggers the misregulation of many genes, which in turn results in developmental failure of NT embryos [14]. This can be corrected by knocking out or knocking down Xist and such Xist-repressed NT embryos develop to term with high efficiency (approximately 15\%) [14, 15]. Secondly, defects in placenta formation have been shown in NT embryos [16, 17]. To circumvent this situation, complementation by trophoblast cells derived from tetraploid fertilized embryos is one reasonable approach [18]. Thirdly, RNA-seq analyses have identified the genes that are often misregulated in NT embryos, as compared to IVF embryos [19-21]. Matoba et al. found reprogramming-resistant regions that are marked by histone $\mathrm{H} 3$ lysine 9 trimethylation (H3K9me3) [19]. The reduction of $\mathrm{H} 3 \mathrm{~K} 9 \mathrm{me} 3$ by overexpressing enzymes that can remove the H3K9 mark, greatly improves the development of NT embryos in several mammalian species, including mice, cows, monkeys, and humans [20, 22-25]. We have also shown that the treatment of mouse NT embryos with epigenetic modifiers (trichostatin A and vitamin C) corrects abnormally high $\mathrm{H} 3 \mathrm{~K} 9 \mathrm{me} 3$ levels and greatly enhances the development of NT embryos (from nearly $0 \%$ to $15 \%$ ) [26]. A recent study reported defects in the expression of imprinting genes that are marked by histone $\mathrm{H} 3$ lysine 27 trimethylation (H3K27me3) in mouse NT embryos [27]. Apart from these reprogramming errors, aberrant DNA re-methylation and silencing of the key imprinting gene have recently been shown to impact cloning efficiencies [28, 29]. Since the application of genome-wide approaches to NT embryos, recurrent reprogramming errors in NT embryos have been found. It is likely that the current efficiency of animal cloning will be further improved in the near future by correcting these reprogramming errors, possibly through simultaneous correction of two or more of the above-mentioned errors [27].

In summary, NT to eggs/oocytes not only provides a route to produce cloned animals, but also provides an opportunity to in- vestigate the reasons why somatic nuclei are resistant to nuclear reprogramming (Fig. 1). A major issue has been how reprogramming mechanisms can be analyzed using NT to MII eggs/oocytes, due to the limited number of NT embryos produced. However, the recent progresses on genome-wide approaches using a small number of cells, such as single cell RNA-seq and small-scale ChIP-seq, have overcome these obstacles. Moreover, cloning success rate is gradually improving due to the tremendous efforts of scientists, such that we have so far achieved a cloning efficiency of approximately $20 \%$ in mice [27]. Other new and improved methods are still needed to further correct reprogramming errors in NT embryos, possibly by utilizing locus-targeted correction of epigenetic misregulation. Other difficulties with using NT to MII eggs/oocytes are that (1) reprogramming by this method is inevitably accompanied by cell division and DNA replication, such that care is needed when dissecting reprogramming mechanisms (discussed below); (2) NT needs skillful micro-manipulation techniques, which normally require years of training to perfect; and (3) in mice, reprogramming towards totipotency can only be achieved in certain strains.

\section{Transcriptional Reprogramming by NT to Xenopus laevis Oocytes at the Germinal Vesicle Stage}

A Xenopus laevis oocyte at the germinal vesicle $(\mathrm{GV})$ stage contains a giant nucleus called the $\mathrm{GV}$, and active transcription is ongoing in the GV before the oocyte becomes responsive to progesterone, which triggers its maturation to the transcriptionally silent MII stage. Gurdon's group has shown that hundreds of permeabilized mammalian cells can be transplanted into a single GV [30]. Interestingly, the transplanted nuclei begin to express previously silenced genes, including pluripotency genes and oocyte-specific genes $[31,32]$. To induce this transcriptional reprogramming, cell membranes need to be permeabilized in order to allow reprogramming factors to access the transplanted nuclei. One of the biggest advantages of using this technique to analyze reprogramming is that cell division and DNA replication are not required before detecting transcriptional reprograming. Therefore, experimental interventions that affect gene expression are directly related to transcriptional reprogramming in this method. Thus, NT to the Xenopus GV facilitates our mechanistic understanding of transcriptional reprogramming. Indeed, many maternal factors that are involved in reprogramming have been identified using this technique [31-35]. One good example of making the best use of this system is the discovery of actin in the nucleus, referred to as nuclear actin, as a reprogramming factor [36]. It would have been very difficult to analyze functions of actin in reprogramming by other systems, since actin is multifunctional and plays key roles in both the cytoplasm and the nucleus [37]. After NT to the Xenopus GV, the transplanted GV can be isolated and it still maintains reprogramming activity (referred to as the oil GV system), since transcriptional reprogramming is achieved by only the nuclear components. We have shown that transcriptional reprogramming of Pou5f1 (Oct4) is impaired after disrupting nuclear actin polymerization in the isolated $\mathrm{GV}$, which excludes the involvement of cytoplasmic actin. Moreover, in this NT system, we do not have to take into account the fact that polymerized nuclear actin is also involved in cell cycle progression [38]. 


\begin{tabular}{|c|c|c|c|}
\hline Diagram of the system & $\begin{array}{l}\frac{\text { Number of }}{\text { reprogrammed }} \\
\underline{\text { cells }}\end{array}$ & Advantages & Challenges \\
\hline Cloned animal & $\begin{array}{l}1 \text { cell per } \\
1 \text { egg/oocyte }\end{array}$ & $\begin{array}{l}\text {-Somatic nuclei acquire } \\
\text { totipotency } \\
\text {-Yielding ES cells of } \\
\text { high quality } \\
\text { - Understanding barriers } \\
\text { for reprogramming }\end{array}$ & $\begin{array}{l}\text { - Technically demanding } \\
\text { - Recurrent errors in } \\
\text { reprogramming } \\
\text { - Increasing the efficiency } \\
\text { of intra- and interspecies } \\
\text { NT }\end{array}$ \\
\hline $\begin{array}{l}\text { Nuclear transfer to Xenopus GV oocytes } \\
\longrightarrow\end{array}$ & $\begin{array}{l}300 \text { cells per } \\
1 \text { oocyte }\end{array}$ & $\begin{array}{l}\text {-Adequate for analyzing } \\
\text { transcriptional } \\
\text { reprogramming } \\
\text { - No DNA replication and } \\
\text { cell divisions are needed } \\
\text {-Oil GV system }\end{array}$ & $\begin{array}{l}\text { - Cloned animals cannot be } \\
\text { obtained } \\
\text {-Currently, only available } \\
\text { in amphibian oocytes } \\
\text { - Revealing relevance to } \\
\text { other reprogramming } \\
\text { systems }\end{array}$ \\
\hline $\begin{array}{r}\text { Egg/oocyte } \\
\text { extract } \\
\text { (cytoplasmic } \\
\text { fraction) } \\
\begin{array}{r}\text { Yolk and } \\
\text { pigments }\end{array}\end{array} \rightarrow$ & $\begin{array}{l}\sim 10^{6} \text { cells per } \\
1 \text { extract }\end{array}$ & $\begin{array}{l}\text {-Adequate for } \\
\text { biochemical analyses } \\
\text {-Immunodepletion of } \\
\text { maternal factors } \\
\text { - Micro-manipulation } \\
\text { skills are not needed }\end{array}$ & $\begin{array}{l}\text {-Need to confirm } \\
\text { reproducibility in in vivo } \\
\text { systems }\end{array}$ \\
\hline $\begin{array}{l}\text { Overexpression of maternal factors } \\
\text { Forced } \\
\text { expression of } \\
\text { maternal factors } \\
\text { with other } \\
\text { reprogramming } \\
\text { transcription } \\
\text { factors }\end{array}$ & $\begin{array}{l}\text { Depending } \\
\text { on the } \\
\text { efficiency of } \\
\text { iPSC method }\end{array}$ & $\begin{array}{l}\text { - Direct test to identify } \\
\text { factors that enhance the } \\
\text { production of pluripotent } \\
\text { cells } \\
\text { - Rapid screening can be } \\
\text { performed } \\
\text { - Micro-manipulation } \\
\text { skills are not needed }\end{array}$ & $\begin{array}{l}\text {-Different reprogramming } \\
\text { mechanisms between } \\
\text { iPSC and eggs/oocytes } \\
\text { - Revealing relevance to in } \\
\text { vivo roles of maternal } \\
\text { factors }\end{array}$ \\
\hline
\end{tabular}

Fig. 1. Overview of various nuclear reprogramming systems using egg/oocyte materials. Four different reprogramming systems using egg or oocyte materials are summarized. Brief explanations of each system, including their advantages over other systems and challenges that need to be considered, are described. Please refer to relevant sections of the text for more details.

On the other hand, cloned animals cannot be obtained by this NT method. In addition, this type of NT has only been established in Xenopus laevis oocytes and it is unclear whether a similar NT system using GV oocytes can be devised in other species. There is also a concern as to whether reprogramming events observed in this system can be reproduced in other NT systems, such as in intraspecies NT to MII eggs/oocytes. Thus far, many reprogramming factors identified in the Xenopus oocyte NT system have also been shown to serve as reprogramming factors in other systems [33, 39-42]. To summarize, when performing NT to GV oocytes, it is important to understand that this is a specialized system for studying transcriptional reprogramming and its associated nuclear remodeling events, but it should still result in useful information (Fig. 1), as described above.

\section{Partial Reprogramming in Extracts from Eggs and Oocytes}

It is desirable to prepare a large number of reprogrammed cells for biochemical and molecular analyses in order to understand the mechanisms of nuclear reprogramming. However, NT to eggs/ oocytes can produce only a limited number of reprogrammed cells (at most, hundreds of NT embryos in one experiment). Therefore, we and others have attempted to develop egg/oocyte extract-mediated reprogramming systems, in which millions of partially reprogrammed cells can be prepared. Cells incubated in extracts are regarded as partially reprogrammed cells, since extracts are currently able to induce only certain aspects of reprogramming, such as DNA replication and chromatin decondensation, as described below. Kikyo et al. were 
the first to use Xenopus egg extracts to induce nuclear remodeling in permeabilized Xenopus somatic cells [43]. The incorporation of egg-derived proteins into somatic nuclei and a concurrent loss of somatic nuclear proteins were observed during incubation in egg extracts [43]. Reprogramming of DNA replication patterns has also been studied in Xenopus egg extracts [44]. In other types of experiments, Xenopus egg extract-treated cells have been subjected to cell culture by resealing plasma membranes of extract-treated mammalian cells. These cultured extract-treated cells begin to express previously silenced genes, such as Oct4 [45-47]. We have also shown that at least partial reprogramming events, such as exchange of chromatin-associated proteins and changes in histone modifications, can be observed in permeabilized mammalian somatic cells that are incubated in extracts derived from mammalian oocytes [48, 49]. Donor cells can also be incubated in egg/oocyte extracts as a pre-treatment before NT to MII oocytes, to improve the efficiency of animal cloning [50-53].

Apart from the fact that a large number of reprogrammed cells are prepared by this route, the advantage of using extracts is that maternal factors can be easily removed by immunodepletion (Fig. 1). This is advantageous, since the knockdown of maternally stored factors in live eggs and oocytes is challenging. Fractionation of extracts is also a valuable approach to identify the maternal factors responsible for the observed reprogramming events. Moreover, extract treatment does not require egg/oocyte micro-manipulation skills. On the other hand, it is unclear to what extent the reprogramming events that must happen in vivo in eggs and oocytes are recapitulated in extracts in vitro. One clear difference between in vivo reprogramming and in vitro extract-mediated reprogramming is that embryonic transcription is not induced during the incubation of permeabilized cells in Xenopus or mammalian extracts. If one can achieve a transcriptionally competent extract, the detailed molecular mechanisms of transcriptional reprogramming could be revealed since in vitro analyses enable quantitative measurement of the maternal factors needed to induce transcription in a spatiotemporally controlled manner. The development of extracts that can achieve transcriptional reprogramming may not be far off, since significant progress has been made using axolotl oocyte extracts $[54,55]$.

\section{Overexpression of Maternal Factors to Produce iPSCs}

It has been postulated that maternal factors may enhance reprogramming via the iPSC route. Maekawa et al. screened transcription factors that can enhance iPSC production and identified the maternal transcription factor, Glis1 [56]. Furthermore, other germ cell-enriched factors, such as histone variants Th2a/Th2b, histone chaperone Asfla, nucleoplasmin, H1foo, Obox1, Tcl1, and Tcl1b1, have been shown to accelerate iPSC-mediated reprogramming [57-61]. This approach is an effective way to directly test the function of candidate genes for the purpose of efficiently obtaining iPSCs (Fig. 1). Therefore, this system can be used as a rapid test to validate reprogramming factors. However, we also need to be cautious about interpreting results when candidate factors do not affect the efficiency of iPSC production; this does not necessarily mean that the tested factors are unrelated to reprogramming in eggs/oocytes, since mechanisms of reprogramming in eggs and oocytes are likely to be different from those in iPSCs [31]. Reprogramming in eggs and oocytes utilizes normal developmental programs, while iPSCs are generated by the overexpression of Yamanaka factors. If we pursue the reprogramming mechanisms of the tested factors in eggs and oocytes, experimental validation in other reprogramming systems is needed.

\section{New Reprogramming Systems}

The ability of MII oocytes to reprogram somatic nuclei has undoubtedly been shown. It is also intriguing to know when the reprogramming ability of oocytes is lost in the course of embryonic development. Mitalipov's group has succeeded in reprogramming cells that are transferred into embryos at the 2-cell stage, as long as the cell cycle is properly synchronized between the donor cell and the recipient oocyte [62]. It is widely regarded that mouse 2-cell embryos still possess totipotency, which may explain their ability to reprogram the transferred somatic nuclei. However, totipotency of embryos is gradually lost in the course of preimplantation development, which is evident from NT experiments using blastomeres at various developmental stages [63]. It would also be interesting to know whether the reprogramming ability of embryos is also impaired or the lack of appropriate reprogramming systems hampers successful reprogramming in embryos at more developed stages. Further investigations are needed to answer these questions.

Cloned animals have also been reported in other than mammals and frogs. For example, methods for cloning zebrafish [64] and flies [65] have been developed, and sturgeon embryos have been produced by interspecies NT [66]. These results imply that the concept of nuclear reprogramming by maternal factors may be generally applicable across species. However, it is still not known to what extent eggs and oocytes of one species can reprogram somatic nuclei of another species. Considering that some nuclear remodeling and gene activation can be induced, even in interspecies NT, there are many common reprogramming factors and mechanisms shared among different species. However, the development of interspecies NT embryos has been largely unsuccessful [12]. More detailed analyses are needed to unravel the causes of developmental failures of interspecies NT embryos. If these issues can be resolved, the next major breakthrough may be the development of efficient interspecies NT techniques, which would potentially pave the way for preserving endangered species and even reviving extinct animals.

\section{Conclusions}

As described in this review, different reprogramming systems have distinct properties. Depending on the purpose of the study, it is important to choose the appropriate reprogramming system. Nuclear reprogramming in NT embryos is a complex process, which is inevitably accompanied by unstoppable and irreversible development. It is sometimes useful to utilize a system that can discriminate each biological process, such as cell cycle progression, chromosome segregation, and transcription. For this purpose, reprogramming systems, such as NT to Xenopus oocytes and extract treatment, are valuable. It is also important to apply currently available state-of-theart technologies to dissect the mechanisms of nuclear reprogramming $[34,67,68]$. With recent progress in this field, many novel insights 
into reprogramming processes in eggs and oocytes will be further revealed in the near future.

\section{Acknowledgments}

I would like to thank Dr Hiroshi Imai for providing a reference for an SRD Young Investigator Award. I am grateful to all my collaborators for their invaluable contributions to our work. I also thank Ms N Backes Kamimura for proofreading the manuscript and the laboratory staff at Kindai University for providing materials for figure preparation. KM is supported by the Human Frontier Science Program (RGP0021/2016); by Japan Society for the Promotion of Science KAKENHI Grant Numbers JP16H01321, JP16H01222, JP17H05045, and JP19H05271; by the Naito Foundation; and by a Kindai University Research Grant (15-I-2).

\section{References}

1. Gurdon JB. The developmental capacity of nuclei taken from intestinal epithelium cells of feeding tadpoles. J Embryol Exp Morphol 1962; 10: 622-640. [Medline]

2. Gurdon JB, Elsdale TR, Fischberg M. Sexually mature individuals of Xenopus laevis from the transplantation of single somatic nuclei. Nature 1958; 182: 64-65. [Medline] [CrossRef]

3. Wilmut I, Schnieke AE, McWhir J, Kind AJ, Campbell KH. Viable offspring derived from fetal and adult mammalian cells. Nature 1997; 385: 810-813. [Medline] [CrossRef]

4. Wakayama T, Perry AC, Zuccotti M, Johnson KR, Yanagimachi R. Full-term development of mice from enucleated oocytes injected with cumulus cell nuclei. Nature 1998; 394: 369-374. [Medline] [CrossRef]

5. Takahashi K, Tanabe K, Ohnuki M, Narita M, Ichisaka T, Tomoda K, Yamanaka S. Induction of pluripotent stem cells from adult human fibroblasts by defined factors. Cell 2007; 131: 861-872. [Medline] [CrossRef]

6. Takahashi K, Yamanaka S. Induction of pluripotent stem cells from mouse embryonic and adult fibroblast cultures by defined factors. Cell 2006; 126: 663-676. [Medline] [CrossRef]

7. Mandai M, Watanabe A, Kurimoto Y, Hirami Y, Morinaga C, Daimon T, Fujihara M, Akimaru H, Sakai N, Shibata Y, Terada M, Nomiya Y, Tanishima S, Nakamura M, Kamao H, Sugita S, Onishi A, Ito T, Fujita K, Kawamata S, Go MJ, Shinohara C, Hata KI, Sawada M, Yamamoto M, Ohta S, Ohara Y, Yoshida K, Kuwahara J, Kitano Y, Amano N, Umekage M, Kitaoka F, Tanaka A, Okada C, Takasu N, Ogawa S, Yamanaka S, Takahashi M. Autologous induced stem-cell-derived retinal cells for macular degeneration. N Engl J Med 2017; 376: 1038-1046. [Medline] [CrossRef]

8. Normile D. iPS cell therapy reported safe. Science 2017; 355: 1109-1110. [Medline] [CrossRef]

9. Egli D, Chen AE, Saphier G, Ichida J, Fitzgerald C, Go KJ, Acevedo N, Patel J, Baetscher M, Kearns WG, Goland R, Leibel RL, Melton DA, Eggan K. Reprogramming within hours following nuclear transfer into mouse but not human zygotes. Nat Commun 2011; 2: 488. [Medline] [CrossRef]

10. Kim K, Doi A, Wen B, Ng K, Zhao R, Cahan P, Kim J, Aryee MJ, Ji H, Ehrlich LI, Yabuuchi A, Takeuchi A, Cunniff KC, Hongguang H, McKinney-Freeman S, Naveiras O, Yoon TJ, Irizarry RA, Jung N, Seita J, Hanna J, Murakami P, Jaenisch R, Weissleder R, Orkin SH, Weissman IL, Feinberg AP, Daley GQ. Epigenetic memory in induced pluripotent stem cells. Nature 2010; 467: 285-290. [Medline] [CrossRef]

11. Ma H, Morey R, O'Neil RC, He Y, Daughtry B, Schultz MD, Hariharan M, Nery JR, Castanon R, Sabatini K, Thiagarajan RD, Tachibana M, Kang E, Tippner-Hedges R, Ahmed R, Gutierrez NM, Van Dyken C, Polat A, Sugawara A, Sparman M, Gokhale S, Amato P, Wolf DP, Ecker JR, Laurent LC, Mitalipov S. Abnormalities in human pluripotent cells due to reprogramming mechanisms. Nature 2014; 511: 177-183. [Medline] [CrossRef]

12. Beyhan Z, Iager AE, Cibelli JB. Interspecies nuclear transfer: implications for embryonic stem cell biology. Cell Stem Cell 2007; 1: 502-512. [Medline] [CrossRef]

13. Narbonne P, Miyamoto K, Gurdon JB. Reprogramming and development in nuclear transfer embryos and in interspecific systems. Curr Opin Genet Dev 2012; 22: 450-458. [Medline] [CrossRef]

14. Inoue K, Kohda T, Sugimoto M, Sado T, Ogonuki N, Matoba S, Shiura H, Ikeda R, Mochida K, Fujii T, Sawai K, Otte AP, Tian XC, Yang X, Ishino F, Abe K, Ogura A. Impeding Xist expression from the active $\mathrm{X}$ chromosome improves mouse somatic cell nuclear transfer. Science 2010; 330: 496-499. [Medline] [CrossRef]

15. Matoba S, Inoue K, Kohda T, Sugimoto M, Mizutani E, Ogonuki N, Nakamura T, Abe K, Nakano T, Ishino F, Ogura A. RNAi-mediated knockdown of Xist can rescue the impaired postimplantation development of cloned mouse embryos. Proc Natl Acad Sci USA 2011; 108: 20621-20626. [Medline] [CrossRef]

16. Wakayama T, Yanagimachi R. Cloning of male mice from adult tail-tip cells. Nat Genet 1999; 22: 127-128. [Medline] [CrossRef]

17. Hill JR, Burghardt RC, Jones K, Long CR, Looney CR, Shin T, Spencer TE, Thompson JA, Winger QA, Westhusin ME. Evidence for placental abnormality as the majo cause of mortality in first-trimester somatic cell cloned bovine fetuses. Biol Reprod 2000; 63: 1787-1794. [Medline] [CrossRef]

18. Lin J, Shi L, Zhang M, Yang H, Qin Y, Zhang J, Gong D, Zhang X, Li D, Li J. Defects in trophoblast cell lineage account for the impaired in vivo development of cloned embryos generated by somatic nuclear transfer. Cell Stem Cell 2011; 8: 371-375. [Medline] [CrossRef]

19. Matoba S, Liu Y, Lu F, Iwabuchi KA, Shen L, Inoue A, Zhang Y. Embryonic development following somatic cell nuclear transfer impeded by persisting histone methylation. Cell 2014; 159: 884-895. [Medline] [CrossRef]

20. Liu W, Liu X, Wang C, Gao Y, Gao R, Kou X, Zhao Y, Li J, Wu Y, Xiu W, Wang S, Yin J, Liu W, Cai T, Wang H, Zhang Y, Gao S. Identification of key factors conquering developmental arrest of somatic cell cloned embryos by combining embryo biopsy and single-cell sequencing. Cell Discov 2016; 2: 16010. [Medline] [CrossRef]

21. Liu Y, Wu F, Zhang L, Wu X, Li D, Xin J, Xie J, Kong F, Wang W, Wu Q, Zhang D, Wang R, Gao S, Li W. Transcriptional defects and reprogramming barriers in somatic cell nuclear reprogramming as revealed by single-embryo RNA sequencing. BMC Genomics 2018; 19: 734. [Medline] [CrossRef]

22. Liu Z, Cai Y, Wang Y, Nie Y, Zhang C, Xu Y, Zhang X, Lu Y, Wang Z, Poo M, Sun Q. Cloning of macaque monkeys by somatic cell nuclear transfer. Cell 2018; 172: 881-887.e7. [Medline] [CrossRef]

23. Chung YG, Matoba S, Liu Y, Eum JH, Lu F, Jiang W, Lee JE, Sepilian V, Cha KY, Lee DR, Zhang Y. Histone demethylase expression enhances human somatic cell nuclear transfer efficiency and promotes derivation of pluripotent stem cells. Cell Stem Cell 2015; 17: 758-766. [Medline] [CrossRef]

24. Liu X, Wang Y, Gao Y, Su J, Zhang J, Xing X, Zhou C, Yao K, An Q, Zhang Y. H3K9 demethylase KDM4E is an epigenetic regulator for bovine embryonic development and a defective factor for nuclear reprogramming. Development 2018; 145: 145. [Medline] [CrossRef]

25. Ruan D, Peng J, Wang X, Ouyang Z, Zou Q, Yang Y, Chen F, Ge W, Wu H, Liu Z, Zhao Y, Zhao B, Zhang Q, Lai C, Fan N, Zhou Z, Liu Q, Li N, Jin Q, Shi H, Xie J, Song H, Yang X, Chen J, Wang K, Li X, Lai L. XIST derepression in active X chromosome hinders pig somatic cell nuclear transfer. Stem Cell Reports 2018; 10: 494-508. [Medline] [CrossRef]

26. Miyamoto K, Tajima Y, Yoshida K, Oikawa M, Azuma R, Allen GE, Tsujikawa T, Tsukaguchi T, Bradshaw CR, Jullien J, Yamagata K, Matsumoto K, Anzai M, Imai H, Gurdon JB, Yamada M. Reprogramming towards totipotency is greatly facilitated by synergistic effects of small molecules. Biol Open 2017; 6: 415-424. [Medline] [CrossRef]

27. Matoba S, Wang H, Jiang L, Lu F, Iwabuchi KA, Wu X, Inoue K, Yang L, Pres W, Lee JT, Ogura A, Shen L, Zhang Y. Loss of H3K27me3 imprinting in somatic cell nuclear transfer embryos disrupts post-implantation development. Cell Stem Cell 2018; 23: 343-354.e5. [Medline] [CrossRef]

28. Yu D, Wang J, Zou H, Feng T, Chen L, Li J, Qi X, Li Z, Duan X, Xu C, Zhang L, Long X, Lan J, Chen C, Wang C, Xu X, Ren J, Zhao Y, Hu X, Lian Z, Men H, Pan D, Li N, Capecchi MR, Du X, Zhao Y, Wu S. Silencing of retrotransposon-derived imprinted gene RTL1 is the main cause for postimplantational failures in mammalian cloning. Proc Natl Acad Sci USA 2018; 115: E11071-E11080. [Medline] [CrossRef]

29. Gao R, Wang C, Gao Y, Xiu W, Chen J, Kou X, Zhao Y, Liao Y, Bai D, Qiao Z, Yang L, Wang M, Zang R, Liu X, Jia Y, Li Y, Zhang Y, Yin J, Wang H, Wan X, Liu W, Zhang Y, Gao S. Inhibition of aberrant DNA re-methylation improves post-implantation development of somatic cell nuclear transfer embryos. Cell Stem Cell 2018; 23: 426-435. e5. [Medline] [CrossRef]

30. Halley-Stott RP, Pasque V, Astrand C, Miyamoto K, Simeoni I, Jullien J, Gurdon JB. Mammalian nuclear transplantation to Germinal Vesicle stage Xenopus oocytes - a method for quantitative transcriptional reprogramming. Methods 2010; 51: 56-65. [Medline] [CrossRef]

31. Jullien J, Pasque V, Halley-Stott RP, Miyamoto K, Gurdon JB. Mechanisms of nuclear reprogramming by eggs and oocytes: a deterministic process? Nat Rev Mol Cell Biol 2011 12: 453-459. [Medline] [CrossRef]

32. Jullien J, Miyamoto K, Pasque V, Allen GE, Bradshaw CR, Garrett NJ, Halley-Stot RP, Kimura H, Ohsumi K, Gurdon JB. Hierarchical molecular events driven by oocytespecific factors lead to rapid and extensive reprogramming. Mol Cell 2014; 55: 524-536. [Medline] [CrossRef]

33. Jullien J, Astrand C, Halley-Stott RP, Garrett N, Gurdon JB. Characterization of 
somatic cell nuclear reprogramming by oocytes in which a linker histone is required for pluripotency gene reactivation. Proc Natl Acad Sci USA 2010; 107: 5483-5488. [Medline] [CrossRef]

34. Miyamoto K, Nguyen KT, Allen GE, Jullien J, Kumar D, Otani T, Bradshaw CR, Livesey FJ, Kellis M, Gurdon JB. Chromatin accessibility impacts transcriptional reprogramming in oocytes. Cell Reports 2018; 24: 304-311. [Medline] [CrossRef]

35. Miyamoto K, Teperek M, Yusa K, Allen GE, Bradshaw CR, Gurdon JB. Nuclear Wave1 is required for reprogramming transcription in oocytes and for normal development. Science 2013; 341: 1002-1005. [Medline] [CrossRef]

36. Miyamoto K, Pasque V, Jullien J, Gurdon JB. Nuclear actin polymerization is required for transcriptional reprogramming of Oct4 by oocytes. Genes Dev 2011; 25: 946-958. [Medline] [CrossRef]

37. Misu S, Takebayashi M, Miyamoto K. Nuclear actin in development and transcriptional reprogramming. Front Genet 2017; 8: 27. [Medline] [CrossRef]

38. Parisis N, Krasinska L, Harker B, Urbach S, Rossignol M, Camasses A, Dewar J, Morin N, Fisher D. Initiation of DNA replication requires actin dynamics and formin activity. EMBO J 2017; 36: 3212-3231. [Medline] [CrossRef]

39. Jullien J, Astrand C, Szenker E, Garrett N, Almouzni G, Gurdon JB. HIRA dependent H3.3 deposition is required for transcriptional reprogramming following nuclear transfer to Xenopus oocytes. Epigenetics Chromatin 2012; 5: 17. [Medline] [CrossRef]

40. Koziol MJ, Garrett N, Gurdon JB. Tpt1 activates transcription of oct4 and nanog in transplanted somatic nuclei. Curr Biol 2007; 17: 801-807. [Medline] [CrossRef]

41. Jullien J, Vodnala M, Pasque V, Oikawa M, Miyamoto K, Allen G, David SA, Brochard V, Wang S, Bradshaw C, Koseki H, Sartorelli V, Beaujean N, Gurdon J. Gene resistance to transcriptional reprogramming following nuclear transfer is directly mediated by multiple chromatin-repressive pathways. Mol Cell 2017; 65: 873-884.e8. [Medline] [CrossRef]

42. Pasque V, Gillich A, Garrett N, Gurdon JB. Histone variant macroH2A confers resistance to nuclear reprogramming. EMBO J 2011; 30: 2373-2387. [Medline] [CrossRef]

43. Kikyo N, Wade PA, Guschin D, Ge H, Wolffe AP. Active remodeling of somatic nuclei in egg cytoplasm by the nucleosomal ATPase ISWI. Science 2000; 289: 2360-2362. [Medline] [CrossRef]

44. Lemaitre JM, Danis E, Pasero P, Vassetzky Y, Méchali M. Mitotic remodeling of the replicon and chromosome structure. Cell 2005; 123: 787-801. [Medline] [CrossRef]

45. Hansis C, Barreto G, Maltry N, Niehrs C. Nuclear reprogramming of human somatic cells by xenopus egg extract requires BRG1. Curr Biol 2004; 14: 1475-1480. [Medline] [CrossRef]

46. Miyamoto K, Furusawa T, Ohnuki M, Goel S, Tokunaga T, Minami N, Yamada M, Ohsumi K, Imai H. Reprogramming events of mammalian somatic cells induced by Xenopus laevis egg extracts. Mol Reprod Dev 2007; 74: 1268-1277. [Medline] [CrossRef]

47. Miyamoto K, Yamashita T, Tsukiyama T, Kitamura N, Minami N, Yamada M, Imai H. Reversible membrane permeabilization of mammalian cells treated with digitonin and its use for inducing nuclear reprogramming by Xenopus egg extracts. Cloning Stem Cells 2008; 10: 535-542. [Medline] [CrossRef]

48. Miyamoto K, Tsukiyama T, Yang Y, Li N, Minami N, Yamada M, Imai H. Cell-free extracts from mammalian oocytes partially induce nuclear reprogramming in somatic cells. Biol Reprod 2009; 80: 935-943. [Medline] [CrossRef]

49. Miyamoto K, Nagai K, Kitamura N, Nishikawa T, Ikegami H, Binh NT, Tsukamoto S, Matsumoto M, Tsukiyama T, Minami N, Yamada M, Ariga H, Miyake M, Kawarasaki T, Matsumoto K, Imai H. Identification and characterization of an oocyte factor required for development of porcine nuclear transfer embryos. Proc Natl Acad Sci USA 2011; 108: 7040-7045. [Medline] [CrossRef]

50. Liu Y, Østrup O, Li J, Vajta G, Kragh PM, Purup S, Callesen H. Cell colony formation induced by Xenopus egg extract as a marker for improvement of cloned blastocyst formation in the pig. Cell Reprogram 2011; 13: 521-526. [Medline] [CrossRef]

51. Liu Y, Ostrup O, Li J, Vajta G, Lin L, Kragh PM, Purup S, Hyttel P, Callesen H. Increased blastocyst formation of cloned porcine embryos produced with donor cells pre- treated with Xenopus egg extract and/or digitonin. Zygote 2012; 20: 61-66. [Medline] [CrossRef]

52. Yang X, Mao J, Walters EM, Zhao MT, Teson J, Lee K, Prather RS. Xenopus egg extract treatment reduced global DNA methylation of donor cells and enhanced somatic cell nuclear transfer embryo development in pigs. Biores Open Access 2012; 1: 79-87. [Medline] [CrossRef]

53. Rathbone AJ, Fisher PA, Lee JH, Craigon J, Campbell KH. Reprogramming of ovine somatic cells with Xenopus laevis oocyte extract prior to SCNT improves live birth rate. Cell Reprogram 2010; 12: 609-616. [Medline] [CrossRef]

54. Allegrucci C, Rushton MD, Dixon JE, Sottile V, Shah M, Kumari R, Watson S, Alberio R, Johnson AD. Epigenetic reprogramming of breast cancer cells with oocyte extracts. Mol Cancer 2011; 10: 7. [Medline]

55. Bian Y, Alberio R, Allegrucci C, Campbell KH, Johnson AD. Epigenetic marks in somatic chromatin are remodelled to resemble pluripotent nuclei by amphibian oocyte extracts. Epigenetics 2009; 4: 194-202. [Medline] [CrossRef]

56. Maekawa M, Yamaguchi K, Nakamura T, Shibukawa R, Kodanaka I, Ichisaka T, Kawamura Y, Mochizuki H, Goshima N, Yamanaka S. Direct reprogramming of somatic cells is promoted by maternal transcription factor Glis1. Nature 2011; 474 225-229. [Medline] [CrossRef]

57. Kunitomi A, Yuasa S, Sugiyama F, Saito Y, Seki T, Kusumoto D, Kashimura S, Take M, Tohyama S, Hashimoto H, Egashira T, Tanimoto Y, Mizuno S, Tanaka S, Okuno H, Yamazawa K, Watanabe H, Oda M, Kaneda R, Matsuzaki Y, Nagai T, Okano H, Yagami KI, Tanaka M, Fukuda K. H1 foo has a pivotal role in qualifying induced pluripotent stem cells. Stem Cell Reports 2016; 6: 825-833. [Medline] [CrossRef]

58. Khaw SL, Min-Wen C, Koh CG, Lim B, Shyh-Chang N. Oocyte factors suppress mitochondrial polynucleotide phosphorylase to remodel the metabolome and enhance reprogramming. Cell Reports 2015; 12: 1080-1088. [Medline] [CrossRef]

59. Wu L, Wu Y, Peng B, Hou Z, Dong Y, Chen K, Guo M, Li H, Chen X, Kou X, Zha Y, Bi Y, Wang Y, Wang H, Le R, Kang L, Gao S. Oocyte-specific Homeobox 1, Obox 1, facilitates reprogramming by promoting mesenchymal-to-epithelial transition and mitigating cell hyperproliferation. Stem Cell Reports 2017; 9: 1692-1705. [Medline] [CrossRef]

60. Shinagawa T, Takagi T, Tsukamoto D, Tomaru C, Huynh LM, Sivaraman P, Kumarevel T, Inoue K, Nakato R, Katou Y, Sado T, Takahashi S, Ogura A, Shirahige $\mathbf{K}$, Ishii S. Histone variants enriched in oocytes enhance reprogramming to induced pluripotent stem cells. Cell Stem Cell 2014; 14: 217-227. [Medline] [CrossRef]

61. Gonzalez-Muñoz E, Arboleda-Estudillo Y, Otu HH, Cibelli JB. Cell reprogramming. Histone chaperone ASF1A is required for maintenance of pluripotency and cellular reprogramming. Science 2014; 345: 822-825. [Medline] [CrossRef]

62. Kang E, Wu G, Ma H, Li Y, Tippner-Hedges R, Tachibana M, Sparman M, Wolf DP, Schöler HR, Mitalipov S. Nuclear reprogramming by interphase cytoplasm of two-cell mouse embryos. Nature 2014; 509: 101-104. [Medline] [CrossRef]

63. Hiiragi T, Solter D. Reprogramming is essential in nuclear transfer. Mol Reprod Dev 2005; 70: 417-421. [Medline] [CrossRef]

64. Siripattarapravat K, Pinmee B, Venta PJ, Chang CC, Cibelli JB. Somatic cell nuclear transfer in zebrafish. Nat Methods 2009; 6: 733-735. [Medline] [CrossRef]

65. Haigh AJ, MacDonald WA, Lloyd VK. The generation of cloned Drosophila melanogaster. Genetics 2005; 169: 1165-1167. [Medline] [CrossRef]

66. Fatira E, Havelka M, Labbé C, Depincé A, Iegorova V, Pšenička M, Saito T. Application of interspecific Somatic Cell Nuclear Transfer (iSCNT) in sturgeons and an unexpectedly produced gynogenetic sterlet with homozygous quadruple haploid. Sci Rep 2018; 8: 5997. [Medline] [CrossRef]

67. Djekidel MN, Inoue A, Matoba S, Suzuki T, Zhang C, Lu F, Jiang L, Zhang Y. Reprogramming of chromatin accessibility in somatic cell nuclear transfer is DNA replication independent. Cell Reports 2018; 23: 1939-1947. [Medline] [CrossRef]

68. Hörmanseder E, Simeone A, Allen GE, Bradshaw CR, Figlmüller M, Gurdon J, Jullien J. H3K4 methylation-dependent memory of somatic cell identity inhibits reprogramming and development of nuclear transfer embryos. Cell Stem Cell 2017; 21: 135-143.e6. [Medline] [CrossRef] 